\title{
Botanical novelties from Sierra de Maigualida, southern Venezuela. II
}

\author{
José R. Grande ${ }^{1 *}$, Jacquelyn Kallunki², María M. Arbo³, Paul E. Berry", Otto Huber ${ }^{5}$ \& Ricarda Riina ${ }^{4,6}$ \\ ${ }^{1}$ Postgrado en Botánica, Instituto de Biología Experimental, Facultad de Ciencias, Universidad Central de Venezuela, Calle Suapure, \\ Colinas de Bello Monte, Apartado 47114, Caracas 1041-A, Distrito Capital, Venezuela; jose.r.grande@gmail.com \\ ${ }^{2}$ Associate Director and Curator of the Herbarium, New York Botanical Garden, Bronx, NY 10458-5126, USA; jkallunki@nybg.org \\ ${ }^{3}$ Curadora del Herbario CTES, Instituto de Botánica del Nordeste, C.C. 209-3400 Corrientes, Argentina; arbo@agr.unne.edu.ar \\ ${ }^{4}$ University of Michigan Herbarium and Department of Ecology and Evolutionary Biology, 3600 Varsity Drive, \\ Ann Arbor, MI 48108, USA; peberry@umich.edu \\ 5Fundación Instituto Botánico de Venezuela "Dr. Tobías Lasser”, Herbario Nacional de Venezuela, Universidad Central de Venezuela, \\ Apartado 2156, Caracas, Distrito Capital, Venezuela; huberotto8@gmail.com \\ ${ }^{6}$ Real Jardín Botánico, CSIC, Plaza de Murillo 2, E-28014 Madrid, Spain; rriina@rjb.csic.es
}

\begin{abstract}
Grande, J.R., Kallunki, J., Arbo, M.M., Berry, P.E., Huber, O. \& Riina, R. 2012. Botanical novelties from Sierra de Maigualida, southern Venezuela. II. Anales Jard. Bot. Madrid 69(1): 7-19.

Four new species, Siphocampylus acanthidiotrichus J.R. Grande (Campanulaceae), Phyllanthus huberi Riina \& P.E. Berry (Phyllanthaceae), Sohnreyia maigualidensis J.R. Grande \& Kallunki (Rutaceae), and Turnera maigualidensis J.R. Grande \& Arbo (Turneraceae) are described and illustrated from the summit areas of Sierra de Maigualida in the Guayana Highlands of southern Venezuela. To date, one genus, 32 species, one subspecies, and one variety of angiosperms are known only from the Maigualida meadows and shrublands, between $1800 \mathrm{~m}$ and the highest elevation areas at $2400 \mathrm{~m}$. Here we describe the first iteroparous species for the genus Sohnreyia K. Krause, a Turnera L. species with apically villose, apiculate petals, and a Siphocampylus Pohl species with aculeiform hairs and pinnatisect leaves. The new species, Siphocampylus acanthidiotrichus, together with S. tillettii Steyerm., represents a morphologically distinct subgroup within the genus.
\end{abstract}

Keywords: Campanulaceae, Guayana Highlands, Guiana Shield, Pantepui, Phyllanthaceae, Rutaceae, taxonomy, Turneraceae.

\section{INTRODUCTION}

This is the second installment of a series of papers updating the floristic knowledge of Sierra de Maigualida, a relatively recently discovered granitic mountain range in southern Venezuela which is sorrounded by several typical Guayanan sandstone table mountains (tepuis). A description of the geography, geology and vegetation of this mountain range, including a detailed map, can be found in Huber $\&$ al. (1997) and in the first issue of this series (Nozawa \& al., 2010). A preliminary checklist of the vascular plant species of the Sierra de Maigualida is given in Rodríguez \& al. (2008), but a more detailed one, including floristic patterns, as well as the history of its botanical exploration, is in preparation (Grande \& al., in prep.).

Including the results shown in the present work, 37 new species, two new subspecies and one new variety of an-

\section{Resumen}

Grande, J.R., Kallunki, J., Arbo, M.M., Berry, P.E., Huber, O. \& Riina, R. 2012. Novedades botánicas de la Sierra de Maigualida, sur de Venezuela. II. Anales Jard. Bot. Madrid 69(1): 7-19 (en inglés).

Se describen e ilustran cuatro especies nuevas procedentes de las cumbres de la Sierra de Maigualida: Siphocampylus acanthidiotrichus J.R. Grande (Campanulaceae), Phyllanthus huberi Riina \& P.E. Berry (Phyllanthaceae), Sohnreyia maigualidensis J.R. Grande \& Kallunki (Rutaceae) y Turnera maigualidensis J.R. Grande \& Arbo (Turneraceae). Hasta ahora un género, 32 especies, una subespecie y una variedad de angiospermas se conocen exclusivamente de la Sierra de Maigualida, y todas ellas proceden de herbazales y arbustales desarrollados entre los 1800 m y las áreas más altas, a 2400 m. Aquí, se describen por primera vez una especie iterópara del género Sohnreyia K. Krause (Rutaceae), una especie de Turnera L. con pétalos apiculados apicalmente vilosos y una especie de Siphocampylus Pohl con pelos aculeiformes y hojas pinnatisectas. La nueva especie Siphocampylus acanthidiotrichus representa, junto a S. tillettii Steyerm., un subgrupo morfológicamente distinto dentro del género.

Palabras clave: Campanulaceae, Escudo Guayanés, Pantepui, Phyllanthaceae, Rutaceae, taxonomía, Turneraceae.

giosperms have been described so far from material from the Sierra de Maigualida; of these, 32 species, one subspecies and one variety are endemic. Species considered as endemic do not include Tibouchina buberi Wurdack (Melastomataceae), which is also known from Cerro Ualipano (Wurdack, 1990). References to previously published taxa can be found in Anderson (1995), Croat \& al. (2010), Frodin (1993), Holst (1993, 2002), Kirkbride (1997), Morillo (1993), Pruski (1992, 2011), and Sastre (2001) and see Nozawa \& al. (2010) for the remaining 11. One genus (Huberopappus, Asteraceae) is endemic to Sierra de Maigualida. There are some common traits to the endemic elements from this massif. The new eudicot species described so far from the summits of Sierra de Maigualida are shrubby or suffruticose plants, which tend to have coriaceous leaves with revolute margin, clustered towards the apex of 
branchlets. This common vegetative feature makes those species relatively easy to distinguish from their closest relatives, especially the non-Pantepui taxa. In addition, most of the species described from Maigualida have their vegetative parts covered by hair-like fungal mycelia and/or bryophythes, a condition often shared with other plants from the Pantepui Province.

In the present contribution, four species belonging to four families (Campanulaceae, Phyllanthaceae, Rutaceae and Turneraceae), are described and illustrated. Some of them exhibit remarkable features within their respective genera. This is the first record of an iteroparous species for the genus Sohnreyia (Rutaceae), a Turnera species with apically villose, apiculate petals, and a Siphocampylus species with aculeiform hairs and pinnatisect leaves.

The continuous exploration work and new cartography generated require some corrections on the topographical nomenclature in this region. Localities referring to "Río Chajura" in previously published species [including those in Botanical Novelties from Sierra de Maigualida, southern Venzuela. I (Nozawa \& al., 2010)] are to be changed to Río Yudi, according to the updated geographical information included in Huber (1995), and cited in Huber \& al. (1997).

\section{RESULTS AND DISCUSSION}

\section{Campanulaceae}

The following new species was treated as Siphocampylus sp. A in Flora of the Venezuelan Guayana (Stein, 1998), in which a brief description as well as an illustration. It was not accounted accounted for, however, in the Nuevo Catálogo de la Flora Vascular de Venezuela (Madriz, 2008).

\section{Siphocampylus acanthidiotrichus J.R. Grande, sp. nov.}

Typus: Venezuela. Bolívar: Municipio Cedeño, Sierra de Maigualida, sector nor-oriental, altiplanicie tepuyana ubicada en las cabeceras del Río Yudi ["Río Chajura" in the label], afluente occidental del Río Erebato, aprox. $100 \mathrm{Km}$ (en línea recta) al SW del campamento EntreRíos, $05^{\circ} 33^{\prime} \mathrm{N}$, 651' W, \pm 2100 m, 28-III-1988 (fl), O. Huber 12746 (holotypus, VEN-283600; isotypus, NY).

A reliquis Siphocampylo spaciebus hactenus descriptis differt; caule, calyce ac corolla trichomatibus minutis aculeiformibus tectis.

Subfrutex geniculatus, 0.2-0.5 m altus, caule, calyce ac corolla trichomatibus minutis aculeiformibus tectis. Caulis usque $3 \mathrm{~mm}$ diametro, pustulatus, apicem versus glabrescens. Folia alterna, petiolo $0.45-0.7 \mathrm{~cm}$ longo, pustulis oblongis praedito; lamina ovata e conspicue lobulata pinnatisecta, 1.9$3.4 \mathrm{~cm}$ longa, $0.75-1.5 \mathrm{~cm}$ lata, basi attenuata, margine paulum revoluta, apice acuta, interdum pilis albis, complanatis, erectis usque $1 \mathrm{~mm}$ longis donata; lobulis acutis, laminae pagina pustulis rotundatis et nervis pustulis oblongis praeditis. Inflorescentiae simplices, axillares, versus apicem ramorum nascentes, erectae, 9.1-17 cm longae. Flores 3.8-4.3 $\mathrm{cm}$ longi, trichomatibus minutis aculeiformibus et mamillatis usque $0.15 \mathrm{~mm}$ longis, tecti. Calyx e sparse hispidulo gla- brescens, bypantho turbinato, 4.8-5.1 $\mathrm{mm}$ longo, 4-5, $\mathrm{mm}$ lato, lobulis lineari-triangularibus, apice calloso et margine integro, 5-5.2 mm longis, 1.5-1.6 mm latis. Corolla 3.2-3.9 $\mathrm{cm}$ longa, $0.56-0.73 \mathrm{~cm}$ lata, hispidula, lobulis satis dense pubescentibus, dorsalibus $5.5-7.5 \mathrm{~mm}$ longis, $1.8-2 \mathrm{~mm}$ latis, lateralibus 3.7-5.7 mm longis, 1.7-2.9 mm latis, ventrali 6$8.2 \mathrm{~mm}$ longo, 2.6-3.6 mm lato. Antherarum tubus $4-4.5 \mathrm{~mm}$ longus, 1.8-1.85 mm latus, pilis simplicibus adpressis, albis, usque $0.5 \mathrm{~mm}$ longis, super tres antheras dorsales in parte gibbosa apicali, et crista pilorum setosorum alborum et erectorum super duas antheras ventrales. Fructus membranosus, conicus superficie reticulatus, $4.9 \mathrm{~mm}$ altus, apiculo $1.3 \mathrm{~mm}$ longo inclusive. Semina rotundata, dorsiventraliter tenuiter complanata, ca. $1 \mathrm{~mm}$ longa, diminute foveolata.

Geniculate subshrub, 0.2-0.5 m tall, rooting at the lower nodes. Stems fistulous, the pith reduced to a membrane attached to the inner surface, terete, up to $3 \mathrm{~mm}$ in diameter, conspicuously longitudinally winged, covered by oblong pustules, glabrous except near the apex, where they are glabrescent, with flattened white hairs to $0.5 \mathrm{~mm}$ long, rising from the apex of the pustules, and tiny aculeiform hairs. Leaves simple, alternate, petiolate, petiole with oblong pustules, terete, with winged margins, from 0.45 to $0.7 \mathrm{~cm}$ long, blade ovate, conspicuously lobed to pinnatisect, 1.9-3.4 $\times$ $0.75-1.5 \mathrm{~cm}$, with attenuated base, margin slightly revolute, apex acute, sometimes with erect flattened white hairs up to $1 \mathrm{~mm}$ long, lobes acute, with a verrucose apex (a colleter?), surface of blades with rounded pustules, except in the nerves where they are oblong. Inflorescences simple, axillary, towards the apex of branches, pedicels erect, slightly curved at the apex, 9.1 to $17 \mathrm{~cm}$ long, bracts sinuous or revolute, glabrous or sparsely hispidulous, linear-subulate, 1 $\mathrm{mm}$ long, born to $0.45-3.6 \mathrm{~cm}$ from the base, with the apex verrucose (a colleter?). Flowers 3.8-4.3 cm long, with tiny aculeiform trichomes, slightly recurved upwards, up to 0.15 $\mathrm{mm}$ long, translucent; anteral tube at the same level as the lobes of the corolla at anthesis. Calyx sparsely hispidulous to glabrescent, hairs $0.05-0.1(0.15) \mathrm{mm}$ long, hypanthium turbinate, 4.8-5.1 $\times 4-5.2 \mathrm{~mm}, 10$-costate, more conspicuously so along 5 mean nerves; lobes linear-triangular, with apex verrucose (a colleter?) and the margin entire, 5-5.2 $\times$ 1.5-1.6 mm. Corolla 3.2-3.9 $\times 0.56-0.73 \mathrm{~cm}$, constricted to $2.7-3.8 \mathrm{~mm}$ at $0.65-0.8 \mathrm{~cm}$ from the base, then abruptly widened, with pubescence as the calyx, but denser, and with nipple hairs, some thicker than others; lobes with relatively dense pubescence, dorsal lobes 5.5-7.5 × 1.8-2 mm, linear-oblong, with apex curved downwards briefly, lateral lobes slightly falcate, 3.7-5.7 × 1.7-2.9 mm, ventral lobe slightly curved downwards, 6-8.2 × 2.6-3.6 mm. Staminal tube $0.85-1 \mathrm{~mm}$ wide, glabrous; anteral tube 4-4.5 $\times 1.8$ $1.85 \mathrm{~mm}$, with simple, appressed, white hairs, up to $0.5 \mathrm{~mm}$ long on the gibbous (apical) portion of the three dorsal anthers, and a tuft of white, erect and setose hairs on the apex of the two ventral anthers. Fruit conical, flattened dorsiventrally, with convex sides, membranous, $4.9 \times 4.8 \mathrm{~mm}$ including a beak of $1.3 \mathrm{~mm}$ long, the surface reticulate. Seeds round, slightly flattened dorsiventrally, ca. $1 \mathrm{~mm}$ long, minutely foveate. (Fig. 1). 


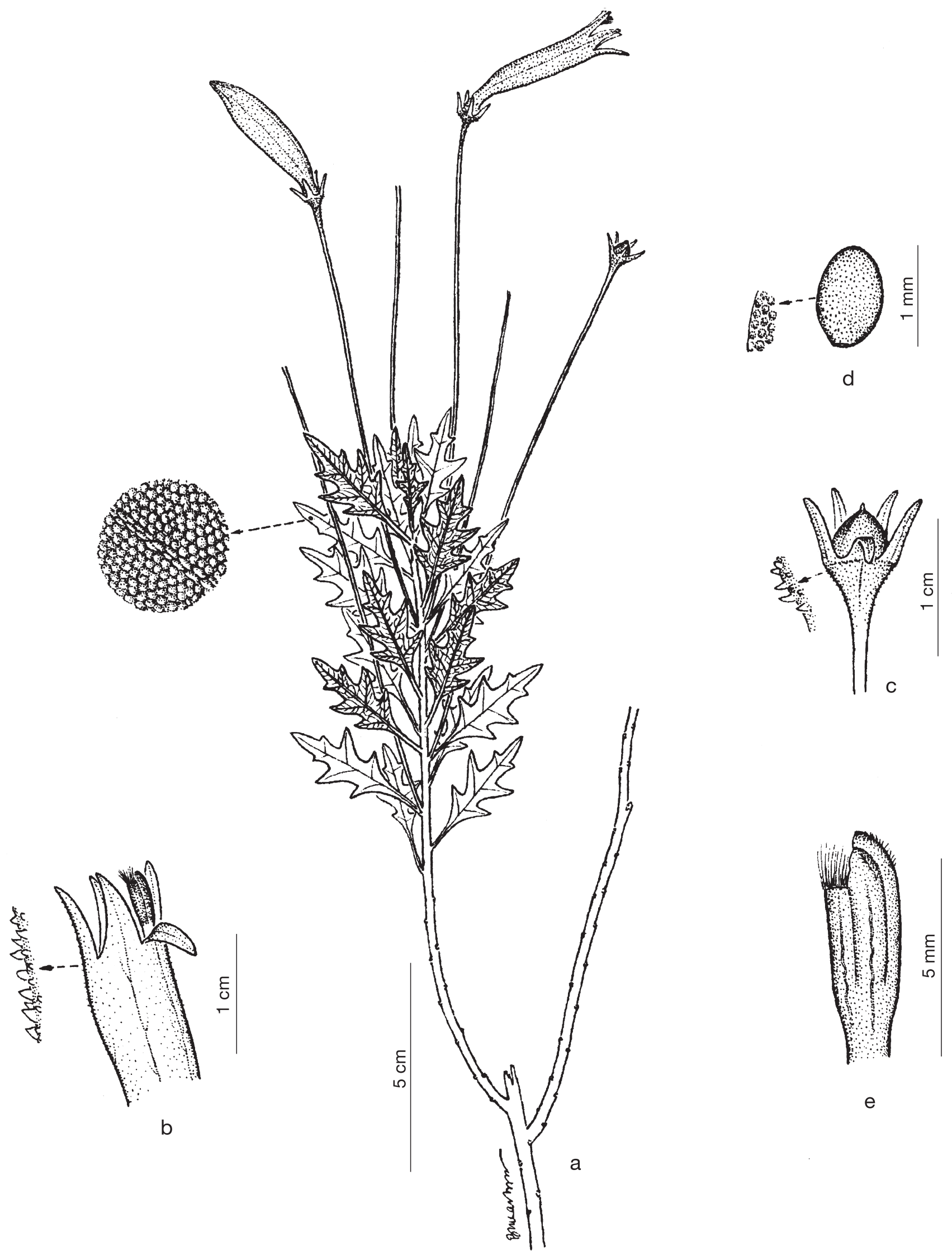

Fig. 1. Siphocampylus acanthidiotrichus: a, habit, detail of adaxial surface of leaf blade; $\mathbf{b}$, apex of the flower, with details of pubescence abaxial side of corolla lobe; $\mathbf{c}$, calyx, with detail of pubescence at the apex of the calyx tube; $\mathbf{d}$, seed, extended surface, showing the tiny foveae; $\mathbf{e}$, antheral tube. (Drawn by Bruno Manara from O. Huber 12746 [holotype]: a, c, f, O. Huber \& L. Izquierdo 12782; b, d, e, from O. Huber 13067). 
Tab. 1. Morphological differences between Siphocampylus acanthidiotrichus and S. tillettii.

\begin{tabular}{lll}
\hline & S. acanthidiotrichus & S. tillettii \\
\hline Trichomes & Tiny aculeiform, up to $0.15 \mathrm{~mm}$ long & Subulate, up to 0.25 mm long \\
Leaf margins & Lobed to pinnatisect, slightly revolute & Serrate \\
Calyx & Sparsely hispidulous to glabrescent, hairs $0.05-0.1(0.15) \mathrm{mm}$ long & Hispid pubescence, subulate hairs 0.07-0.25 mm long \\
Calyx lobes & Entire, 5-5.2 $\times 1.5-1.6 \mathrm{~mm}$ & Serrate, $4.7-11.1 \times 1.1-1.8 \mathrm{~mm}$ \\
Pedicels length (at anthesis) & $9.1-17 \mathrm{~cm}$ & $5.5-13.7 \mathrm{~cm}$ \\
\hline
\end{tabular}

\section{Etymology}

The compound epithet acanthidiotrichus means, in latinized Classical Greek, "with tiny spiny [or aculeiform] hairs", and is derived from ákanthos, spine, -idium, latinised greek substantival suffix for neutral diminutives, and thrix, trichos, hair.

\section{Diagnostic characters}

Siphocampylus acanthidiotrichus is the only known species in the genus with tiny aculeiform trichomes. It is very similar to $S$. tillettii Steyerm., from which it can be differentiated according to the characters listed in Table 1. Although infrageneric, and even generic divisions within subfamily Lobelioideae do not reflect the current phylogenetic hypothesis (Knox \& al., 2008; Lammers, 1998), until now the most thorough classification is that of Wimmer (1953), according to which Siphocampylus acantbidiotrichus and $S$. tillettii are part of Siphocampylus sect. Macrosiphon subsect. Eusiphocampylus (A. DC.) E. Wimm. Both species can be assigned to this subsection by virtue of their corolla tubes, which are 2-5 times longer than the limb, and their filaments, which are adnate to the corolla from the base to the constriction. By virtue of their habit (geniculate, rooting at lower nodes and not exceeding $0.5 \mathrm{~m}$ high), surface of leaves and stems (bullate), texture and margins of leaves (coriaceous), relatively long pedicels, and corolla with reddish-orange tube and yellow lobes, they could be considered part of a small, well-delimited group restricted to the Guayana Highlands.

\section{Distribution and habitat}

Siphocampylus acantbidiotrichus is endemic to Sierra de Maigualida, where it grows in shrubby meadows at 2100$2150 \mathrm{~m}$ elevation, on soils developed from granitic substrate. According to the information in the collection labels it is not clear whether $S$. acanthidiotrichus grows on peatlands or on rocky exposures. Siphocampylus tillettii, the most similar species, is restricted to rock outcrops on Cerro Marahuaka (Stein, 1998; Steyermark, 1978), a sandstone table mountain in western Venezuelan Guayana.

\section{Paratypi}

VENEZUELA. Amazonas: Departamento Atures, Sierra de Maiguali$\mathrm{da}$, sector nor-oriental, altiplanicie disectada de granito en las cabeceras nororientales del Río Iguana, afluente del Río Ventuari, $05^{\circ} 40^{\prime} \mathrm{N}$, $65^{\circ} 08^{\prime} \mathrm{W}, \pm 2150 \mathrm{~m}, 24-\mathrm{XI}-1989$, (fl, fr), O. Huber 13067 (VEN-372737, MO), Cabeceras del Río Asita en la sección nororiental de la Sierra de Maigualida, grandes extensiones de turberas con herbazales arbustivos tepuyanos, 5⒊' $\mathrm{N}, 65^{\circ} 13^{\prime} \mathrm{W}, \pm 2150 \mathrm{~m}, 8$-III-1996, (fl), O. Huber $\mathcal{E} R$ Riina 13634 (Unicata: VEN-301116). Bolívar: Distrito Cedeño, Sierra de Maigualida, sector nor-oriental, altiplanicie tepuyana disectada sobre granito en las cabeceras del Río Yudi ["Río Chajura" in the label], afluente occidental del Río Erebato, aprox. $100 \mathrm{~km}$ (en línea recta) al SW del Campamento EntreRíos, $05^{\circ} 33^{\prime} \mathrm{N}, 65^{\circ} 13^{\prime} \mathrm{W}, 2100 \mathrm{~m}, 18-\mathrm{XI}-1988$, (fl), O. Huber E L. Izquierdo 12782 (VEN-372722; MO, 2 sheets).

\section{Phyllanthaceae}

Following current classifications based on phylogenetic hypotheses (APG III, 2009; Hoffmann \& al., 2006; Stevens, 2011), the genus Phyllanthus L. is included within the family Phyllanthaceae, formerly considered a member of Euphorbiaceae and included as such in the Flora of the Venezuelan Guayana (Webster, 1999).

\section{Phyllanthus huberi Riina \& P.E. Berry, sp. nov.}

Typus: Venezuela. Bolívar: Distrito Cedeño, Sierra de Maigualida, sector nor-oriental, altiplanicie disectada sobre granito en las cabeceras del Río Yudi ["Río Chajura" in the label], afluente occidental del Río Erebato, aprox. 100 $\mathrm{km}$ (en línea recta) al SW del Campamento EntreRíos, $05^{\circ} 33^{\prime} \mathrm{N}, 65^{\circ} 13^{\prime} \mathrm{W}, 2100 \mathrm{~m}$, 18.xi.1988, (fl, fr), O. Huber $\mathcal{E} L$. Izquierdo 12806 (holotypus, VEN; isotypi, DAV, MA, MYF, $\mathrm{M}, \mathrm{NY})$.

Phyllantho tepuicolae affinis, sed foliis petiolisque maioribus, apice foliorum retuso, marginibus valde revolutis, pedicello pistillato minori differt.

Frutices monoeci 0.2-1.5 m alti. Caules primores erecti, dense ramosi, cortice irregulariter crustaceo, e griseo nigrescente; ramis teretibus, ascendentibus, $3-9 \mathrm{~cm}$ longis, 1.2-2 $\mathrm{mm}$ diametro, 24-35 foliis praeditis. Folia laminis anguste oblanceolatis, 5-14 mm longis, 2-3 mm latis, coriaceis, glabris, eglandulosis, supra nitentibus, subtus opacis, basi cuneatis, margine integerrimis et valde revolutis; costa supra depressa, subtus suaviter prominenti, venis 4-8, arcuatis, supra obscuris, subtus suaviter prominentibus. Petiolus canaliculatus, abaxialiter teres, 1-1.5 mm longus. Stipulae persistentes, anguste triangulares, coriaceae, glabrae, 1.5$2 \mathrm{~mm}$ longae, 0.4-0.6 mm latae, apice ex acuto acuminatae, margine byalinae, integerrimae, paulo undulatae vel suaviter fimbriatae. Inflorescetiae axillares, bracteis triangularibus, acutis, 0.4-0.5 mm longis. Cimulae staminatae uno alterove flore praeditae, pedicello 0.9-1.5 mm longo; sepalis 6, biseriatis, late ellipticis, 1-1.3 mm longis, 0.7-0.9 mm latis, apice obtusis, margine byalinis; disco glandulis 6, discretis, plus minusve rotundatis, $0.2-0.3 \mathrm{~mm}$ diametro; staminibus 3, filamentis liberis vel partialiter connatis; thecis emarginatis, horizontaliter debiscentibus. Flores pistillati praesertim solitarii, 1.5-2.5 mm longi, 1.5-2.5 mm lati, pedicello $2-3 \mathrm{~mm}$ longo; sepalis 6, ex elliptico late ellipticis, suaviter imbricatis, 


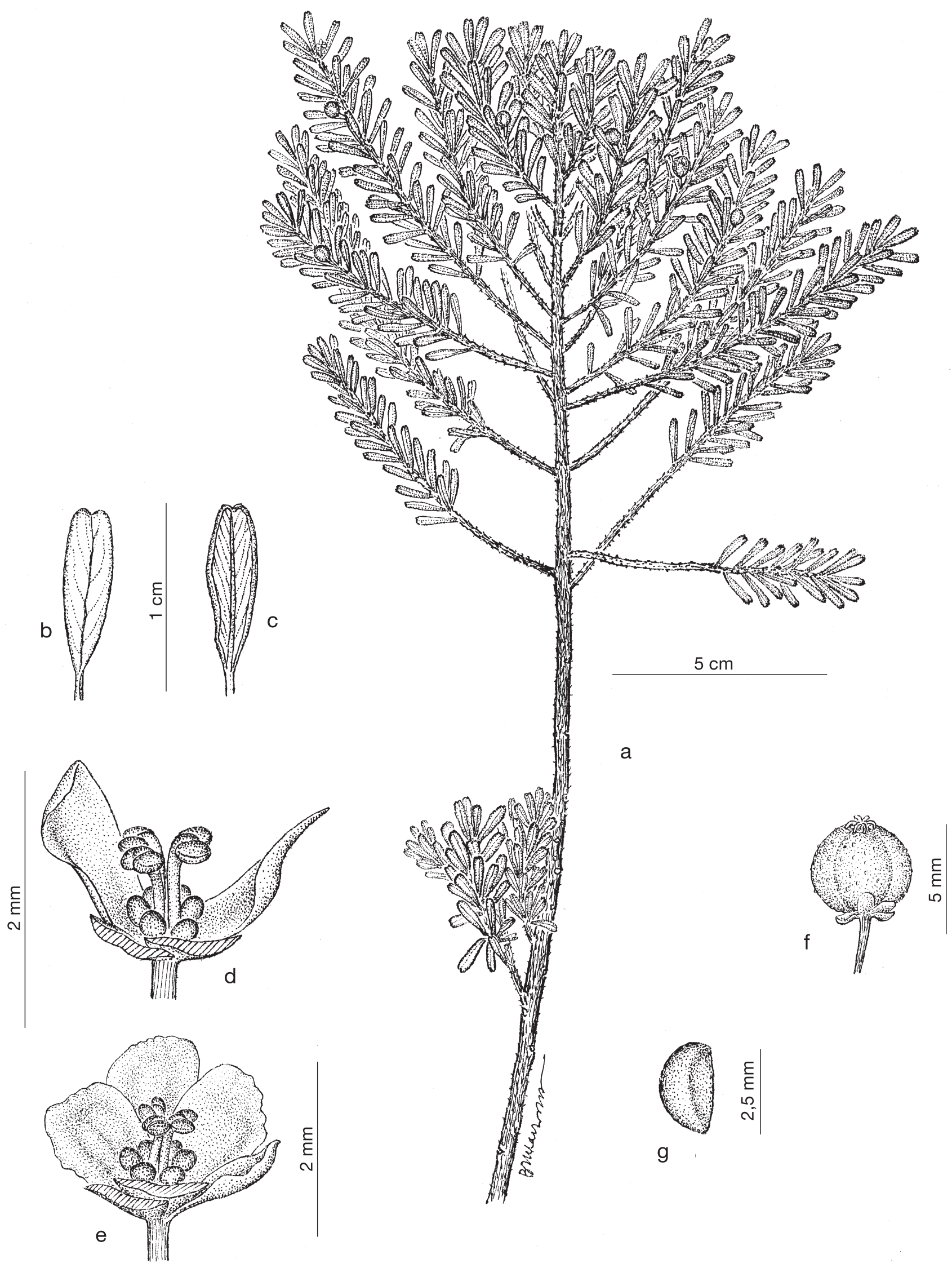

Fig. 2. Phyllanthus huberi: a, habit; b, abaxial side of leaf; $\mathbf{c}$, adaxial side of leaf; $\mathbf{d}$, staminate flower showing detail of anthers and disc glands (four sepals removed); e, staminate flower showing three of the six sepals in detail; f, fruit; g, seed. (Drawn by Bruno Manara from O. Huber \& L. Izquierdo 12806 [holotype]). 
glabris, 1.3-1.5 mm longis, 0.8-1.1 mm latis, apice rotundatis, margine hyalinis; disco segmentis 6 contiguis, margine irregulariter dissectis; ovario globoso, glabro, stylo 3, 0.4-0.5 $\mathrm{mm}$ longo, borizontaliter protenso, bifido, apicibus corniculatis. Capsulae depresse globosae, triloculares, suaviter sulcatae, 3-3.5 mm longae, 4-5 mm latae, extus pance verrucosae, rubrae (in sicco e saturate brunneis nigricantes); ovulis binis in loculo; columella persistenti, $2.5 \mathrm{~mm}$ longa. Semina triquetra, levia, dilute brunnea, 2.2-2.5 mm longa, 1.1-1.3 $\mathrm{mm}$ lata.

Monoecious shrubs 0.2-1.5 m tall. Main stems erect, terete, $3-8 \mathrm{~mm}$ diam., densely branching from the base; bark irregularly crusty, gray to blackish; phyllanthoid branchlets terete, ascending, 3-9 cm long, 1.2-2 mm diam., with 24-35 leaves. Leaf blades narrowly oblanceolate, 5-14 $\times 2-3 \mathrm{~mm}$, coriaceous, glabrous, eglandular, shiny above and dull beneath; base cuneate; apex emarginate; margin entire and strongly revolute; midvein depressed adaxially, raised abaxially; lateral veins 4-8 per side, arching, obscure adaxially, slightly raised abaxially. Petiole terete abaxially, canaliculate adaxially, 1-1.5 mm long. Stipules persistent, narrowly deltate, coriaceus, glabrous, 1.5-2 × 0.4-0.6 mm; apex acute to acuminate; margin hyaline, entire or sometimes undulate or slightly fimbriate. Inflorescences axillary, bracts triangular, acute, $0.4-0.5 \mathrm{~mm}$ long. Staminate cymules with 1-2 flowers, pedicel 0.9-1.5 mm long; sepals 6, biseriate, broadly elliptic, 1-1.3 × 0.7-0.9 mm, apex obtuse, margin hyaline; disc glands 6 , distinct, \pm circular, 0.2-0.3 $\mathrm{mm}$ diam.; stamens 3, filaments free or partially connate; thecae divergent, muticous, emarginate, aperture horizontal. Pistillate flowers usually solitary, $1.5-2.5 \times 1.5-2.5 \mathrm{~mm}$, pedicel $2-3 \mathrm{~mm}$ long; sepals 6 , elliptic to broadly elliptic, slightly imbricate, glabrous, 1.3-1.5 × 0.8-1.1 mm, apex rounded, margin hyaline; disc segments 6 , contiguous, more or less globose to slightly flattened (when rehydrated); ovary globose, glabrous, styles 3, 0.4-0.5 mm long, horizontally spreading, bifid, the tips corniculate. Capsules depressed-globose, trilocular, slightly sulcate, 3-3.5 × 4-5 mm, outer surface slightly verrucose, red (dark brown to blackish on drying); ovules two per locule; columella persistent, $2.5 \mathrm{~mm}$ long. Seeds triquetrous, smooth, light brown, dull, 2.2-2.5 × 1.1-1.3 mm. (Fig. 2).

\section{Etymology}

The species honors our friend and colleague Otto $\mathrm{Hu}$ ber, a dedicated worker on the flora and vegetation of the Guayana Region, and the first person to botanically explore the high ridges of Sierra de Maigualida.

\section{Diagnostic characters}

The only other species of Phyllanthus known to date from the higher altitudes of the Sierra de Maigualida is $P$. obfalcatus Lasser \& Maguire. That species differs, however, in its more numerous leaves on the side branches $(>40)$, its narrower and more falcate leaf blades (1-2 $\mathrm{mm}$ wide), and in having a distinct subapical gland 0.1-0.2 $\mathrm{mm}$ diam. on the lower leaf surface.
Following Webster's key to Pbyllanthus in the Flora of the Venezuelan Guayana (Webster, 1999), P. buberi keys out closest to P. maguirei Jabl. and P. tepuicola Steyerm., both high elevation species to which it is presumably allied phylogenetically and characterized by the lack of laminar glands, bifid styles, muticous/emarginate anthers, and the presence of six disk segments in both flower sexes. Of the two, $P$. huberi is more similar to P. tepuicola, which is endemic to Cerro Duida, to the southwest in Estado Amazonas. Phyllanthus huberi can be distinguished by its larger leaves with an emarginate apex, strongly revolute margins, longer petiole, and shorter pistillate pedicel.

Although Phyllanthus buberi is entirely glabrous, the stems and branchlets of the three specimens cited all have a notable blackish growth that could initially be confused with pubescence. This covering is most likely due to the presence of fungal hyphae, perhaps associated with the very humid and cool conditions at the high elevation shrublands and meadows in which the species occurs. Steyermark (1988) made reference to this same phenomenon in several species of Ilex L. (Aquifoliaceae) from the Guayana Highlands.

\section{Distribution and habitat}

This species is only known from the Sierra de Maigualida, in the Venezuelan Guayana Region, along the border of estado Bolívar and estado Amazonas. It occurs there on sandy soils along streams, at the edge of rock outcrops, and in herbaceous meadows, at 2100-2150 m elevation.

\section{Paratypi}

VENEZUELA. Amazonas: Depto. Atures, Sierra de Maigualida, sector nor-oriental, altiplanicie disectada de granito en las cabeceras nor-orientales del Río Iguana, afluente del Río Ventuari, $05^{\circ} 40^{\prime} \mathrm{N}, 65^{\circ} 08^{\prime} \mathrm{W}, 2150$ m, 24-XI-1989, (fl, fr), O. Huber 13064 (DAV, VEN; 3 sheets to be distributed). Bolívar: Distrito Cedeño, Sierra de Maigualida, sector nororiental, altiplanicie tepuyana ubicada en las cabeceras del Río Yudi ["Río Chajura" in the label], afluente occidental del Río Erebato, aprox. $100 \mathrm{~km}$ (en línea recta) al SW del Campamento EntreRíos, $05^{\circ} 33^{\prime} \mathrm{N}, 65^{\circ} 13^{\prime} \mathrm{W}$, 2100 m, 28-III-1998, (fl, fr), O. Huber 12739 (DAV, MA, VEN).

\section{RUTACEAE}

Sobnreyia K. Krause is a small genus with four species from the Amazonian-Guayanan region of northern South America (Appelhans \& al., 2011). As presently understood it is a member of tribe Spathelieae, subfamily Spathelioideae, together with the related Spathelia L. and Dictyoloma A. Juss. Despite some early disagreement about its taxonomic placement and circumscription, this genus is currently accepted as a member of the family Rutaceae, order Sapindales (Stern \& Brizicky, 1960; Chase \& al., 1999; Groppo \& al., 2008; Appelhans \& al., 2011; Stevens, 2011).

So far, species described in Sohnreyia are characterized by its apically crowded paripinnate leaves, with 7-24 pairs of leaflets, phyllothyrsiform terminal inflorescences (inflorescence terminology following Austin, 1973), and fruits 2-3-winged, wider than long. They are monopodial and semelparous, a combination present also in some monocots like Agave L. (Agavaceae-Asparagaceae) and Corypha L. 
(Arecaceae) but very rare in dicots (Janzen, 1976; Bell, 1980). León \& Alaín (1951), in fact, reported that plants of the related Spathelia die six months after flowering, once the fruits have ripened. Collections made in the late 1980's and early 1990's above $2000 \mathrm{~m}$ elevation in the highlands of Sierra de Maigualida (Central Venezuelan Guayana), however, have revealed the existence of individuals similar to Sohnreyia ulei (Engl. ex Harms) Appelhans \& Kessler that are capable of producing axillary inflorescences and show an iteroparous condition, being monopodial or sometimes sympodial. These individuals, additionally, are relatively shorter and exhibit a very dense ferruginous pubescence on young organs and leaves with only 2-4(5) pairs of smaller, rugose leaflets (Kallunki, 2005). A deeper examination of the complete set of specimens revealed further differences in the type and distribution of the pubescence, as well as in the filaments, ovary, stigma, and fruit. All together, they suggest a substantial differentiation of the populations on granitic substrate at higher altitudes in Sierra de Maigualida from those that occur on sandstone within a wider altitudinal range, and convinced the authors that it merits specific recognition.

\section{Sohnreyia maigualidensis J.R. Grande \& Kallunki, sp. nov.}

Typus: Venezuela. Amazonas: Departamento Atures, Sierra de Maigualida, sector nor-oriental, altiplanicie disectada de granito en las cabeceras nor-orientales del Río Iguana, afluente del Río Ventuari, $05^{\circ} 40^{\prime} \mathrm{N}, 65^{\circ} 08^{\prime} \mathrm{W}, \pm 2150 \mathrm{~m}$, 24-XI-1989 (fl, fr), O. Huber 13063 (holotypus, VEN377776; isotypi, NY, 2 dupl.).

A Sobnreyia uleo, paribus foliolorum paucioribus (2-5 nec 6-20) necnon ramis foliisque junioribus trichomatibus ramosis densis sed postremo deciduis indutis differt.

Frutices 0.5-5(7) m alti, praesertim monopodiales, raro ramosi corona sparsa. Caules juniores, folia, sepala, ovaria necnon fructus, plus minus densa brevi pubescentia stellatis et simplicibus pilis constituta. Pili stellati robro-ferruginei, decidui, (4)5-8-complanato-ramosi, persistentiores in rachi, petiolis, petiolulis, foliolis subtus, inflorescentiae axi calycibusque, praesertim conglomerati in arbuscularum structuras uniformiter subtus distributas in maturis foliolis. Pili simplices byalini, persistentes, paulo recurvati, subtus in costa foliolorum et supra secus marginem, fragiles in senectute. Caules nigricantes, conspicue cicatricosi, cortice paulo fragili. Folia coriacea, (6.5)10.2-28.5 cm longa, (3)4-7-foliolata, 24(5) foliolorum paribus constituta, interdum singulo foliolo in pari basali vel apicali absente, juvenilia e brunneo-ferruginea rubricante, valde obscura pubescentia induta; foliola sessilia vel brevissime petiolata, longe oblongo-ovata vel elliptica, raro elliptico-obovata, coriacea, (2.7)5-12.4 cm longa, 3.1$5.8 \mathrm{~cm}$ lata, basi cordata, rarius obtusa, margine suaviter revoluta, apice obtusa, breviter apiculata; supra nitida, rugosa, parum bullata. Inflorescentia terminalis vel lateralis, singulo flore vel interdum florali alabastro abortante terminata; bracteae floribus subtensae paulo evolutae; bracteae ramis IV et $V$ ordinis subtensae, squamatae, anguste triangulares. Flores praesertim feminini (istius sexi tantum observati), in al- abastro globosi, erecti, pedicellis 1,2-4 mm longis. Sepala parum coriacea, patenti-erecta, 2-2.1 mm longa, 1-1.1 mm lata, valvata, elliptico-oblonga, apice rotundata. Petala membranacea, patentia, alba (cremosa in sicco), 4.3-4.5 mm longa, 3.1-3.3 mm lata, imbricata, late elliptico-ovata, glabra, retrorsus margine ciliata, parum cucullata. Stamina filamentis subulatis, basi alata, alae 0.3-0.8 $\mathrm{mm}$ longa, $0.7 \mathrm{~mm}$ lata, pilis simplicibus, sinuosis, usque $0.9 \mathrm{~mm}$ longis in verticalibus seriebus secus margines costaque abaxialiter (et pilis raris variae longitudinis utrinque conspersis), caeterum glabra; antherae elliptico-ovatae, ca. $1 \mathrm{~mm}$ longae, $0.75 \mathrm{~mm}$ latae. Ovarium 3.2-3.5 mm longum, $3 \mathrm{~mm}$ latum, orbiculare, complanatum, bilobum, maniculatum, ferrugineum, interne glabrum; stigma dilute luteum, sessile, quam ovarium nigricantius (in sicco); gynophorum breve, puberulum. Fructus irregulares, asymmetrici, fere rhomboidales, valde dorsiventraliter compressi, margine alati, basi retusi, ferruginei, dense puberuli brevibus pilis stellatis simplicibus induti, in senectute glabrescentes, (1.34)1.6-2 cm longi, 1.6-2.1 cm lati.

Shrubs $0.5-5(7) \mathrm{m}$ tall, usually monopodial, rarely branched, with a sparse crown. Young stems, leaves, sepals, ovaries, and fruits more or less covered with a dense, short pubescence composed of stellate and simple hairs. Stellate hairs reddish-ferrugineous, deciduous, with (4)5-8 flattened arms, persistent for a longer period on rachises, petioles, petiolules, lower leaflet surfaces, inflorescence axes, and calyces, with tendency to agglomerate, once detached, to form arbusculiform structures evenly distributed on lower surfaces of the mature leaflets. Simple hairs hyaline, persistent, straight or slightly recurved, concentrated on the midrib of lower surfaces of the leaflets and along margins of upper surfaces, broken in senescent tissues. Stems blackened, conspicuously cicatricose, bark somewhat brittle. Leaves coriaceous, (6.5)10.2-28.5 cm long, (3)4-7 foliate, with 2-4(5) pairs of leaflets, sometimes one leaflet of basal pair or of apical pair absent, the juveniles with a brownish-ferrugineous to reddish pubescence; leaflets sessile or very shortly petiolulate, long oblong-ovate to elliptic, rarely elliptic-obovate, coriaceous, (2.7)5-12.4 $\times$ (1.9) $3.1-5.8 \mathrm{~cm}$, the base cordate, rarely obtuse, the margins slightly revolute, the apex obtuse, slightly apiculate; upper leaflet surface lustrous, rugose, slightly bullate, with venation to the fifth order immersed, initially with a dense pubescence, then glabrescent, simple hairs more or less sparse, stellate hairs very sparse along the midrib and the secondary veins; lower leaflet surface ferrugineous and opaque, with prominent nerves, decreasing in prominence from the primary to the tertiary veins (as seen with the naked eye). Inflorescence terminal or lateral, when terminal ramified to the fifth order and bearing flowers congested near the apex of the tertiary ramifications, when lateral arising directly from the stem on a short projection bearing a pair of thyrses, each ramified between the third and the fifth order and bearing flowers on the secondary ramifications, determinate, terminated by a flower or a sometimes aborted floral bud; bracts subtending flowers poorly developed; bracts subtending ramifications of fourth and fifth order scale-like, narrowly triangular. Flowers predomi- 
nantly female (only that type of flower seen), globose in bud, erect, on pedicels 1.2-4 mm long. Sepals somewhat coriaceous, patent-erect, 2-2.1 $\times 1-1.1 \mathrm{~mm}$, valvate, ellipticoblong, apically rounded, the abaxial surface reddish-fer- ruginous, with sparse, reddish, stellate hairs and hyaline simple hairs concentrated toward the margins and on the lower half of the midvein. Petals membranaceous, patent, white (creamy in sicco), 4.3-4.5 × 3.1-3.3 mm, imbricate,

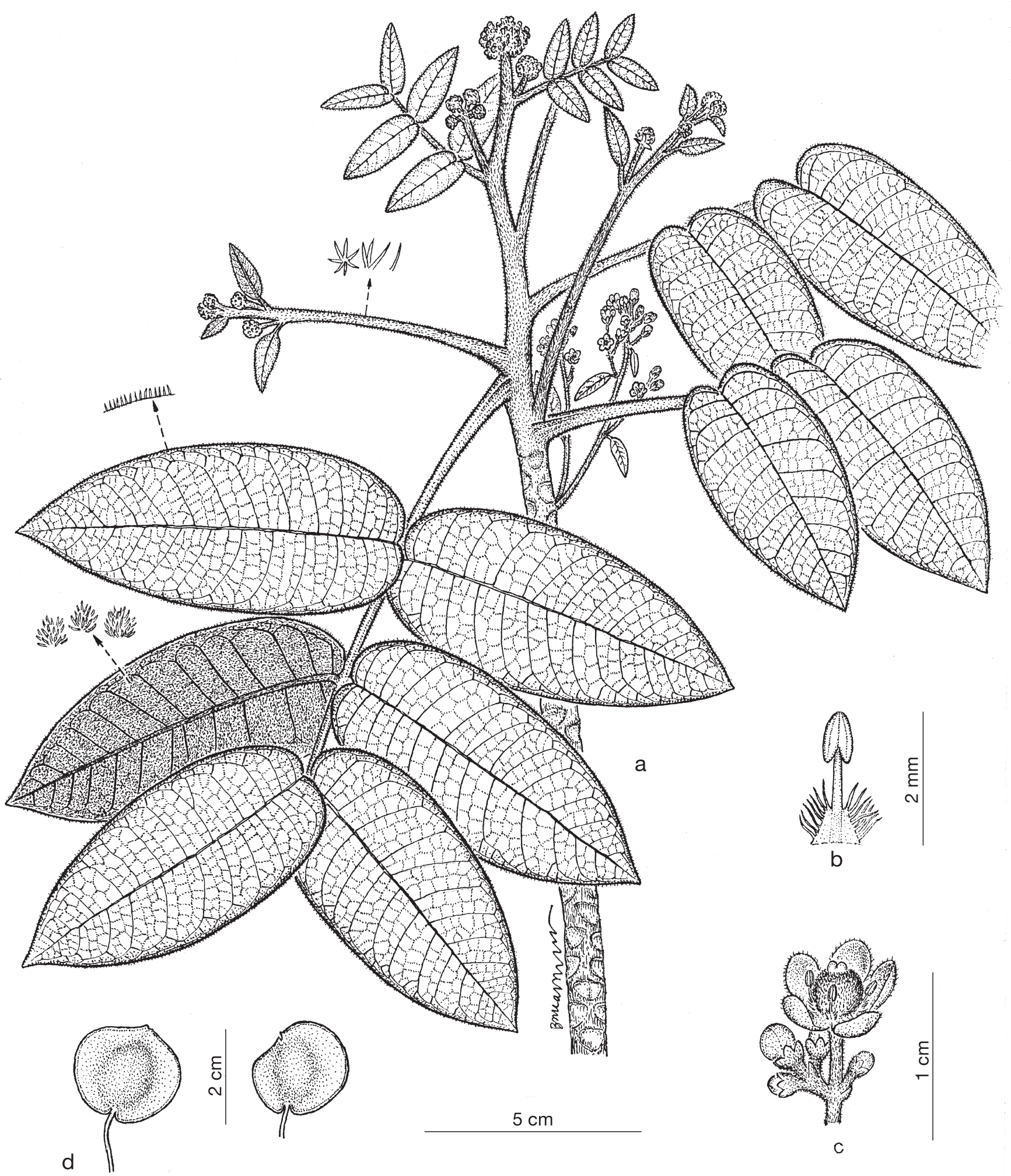

Fig. 3. Sohnreyia maigualidensis: a, habit, included are details of the pubescence of the adaxial and abaxial surfaces of the leaflets; $\mathbf{b}$, stamen, internal side; $\mathbf{c}$, apical portion of a ramification of a terminal inflorescence, showing one flower in anthesis; $\mathbf{d}$, fruits. (Drawn by Bruno Manara; a-d from O. Huber 13063 (holotype), except the terminal inflorescence of a, from O. Huber 13097). 
broadly elliptic-ovate, glabrous, retrorsely ciliate on margin, somewhat cucullate. Stamens light green, 2.1-2.7 mm long, filaments subulate, basally winged, wings thin, $0.3-0.8$ $\times 0.17 \mathrm{~mm}$, with vertical rows of simple sinuous hairs to 0.9 $\mathrm{mm}$ along the margins and the midvein on the abaxial surface (plus some additional hairs of varied length, sparse on both surfaces), the rest glabrous; anthers elliptic-ovate, ca. $1 \times 0.75 \mathrm{~mm}$. Ovary 3.2-3.5 $\times 3 \mathrm{~mm}$, orbicular, flattened, bilobed, adpressed-pubescent, ferrugineous, internally glabrous; stigmas light yellow, sessile, darker than the ovary (in sicco); gynophore short, puberulous. Fruits irregular, asymmetrical, approximately rhomboidal, strongly dorsiventrally compressed, winged, retuse at base, ferrugineous, densely pubescent with short stellate hairs and simple hairs, glabrescent when senescent, (1.34)1.6-2 × (1.18)1.6-2.1 mm. (Figs. 3, 4).

\section{Etymology}

The specific epithet refers to the type locality.

\section{Diagnostic characters}

Since Linné (1760) established Spathelia sorbifolia L., 29 species and one variety in four different genera have been described in the tribe Spathelieae. Fourteen to twenty species are still recognized: one species from Brazil is included in Dictyoloma, with branched stems and semelparous habit, bipinnate leaves, capsular fruits with several ovules, and winged seeds; nine to fourteen species of Spathelia (including or not the variety, considered as a subspecies by Borhidi \& Muñiz [1971]) are exclusive to the Caribbean islands Cuba, Jamaica and the Bahamas; the remaining four, all from northern South America, are included in Sohnreyia (Cowan \& Brizicky, 1960; Proctor, 1982; Kallunki, 2005; Parra-Osorio, 2005; Beurton, 2008; Appelhans \& al., 2011). All the species described in the past as Spathelia and Sobnreya have unbranched stems, semelparous habit and samaroid fruits, and this was the reason for their inclusion in Spathelia sensu lato. But now, species assigned to Spathelia are distinguished by their bright red or pink petals, three or rarely two carpels without secretory cavities, elliptic to oval fruits with the bearing-seed portion generally broader that wings, leaflets often serrate or crenate, seeds with endosperm, and lanceolate embryos (formerly included in Spathelia L. subgen. Spathelia), whereas those taxa with whitish petals, two or rarely three carpels with one large secretory cavity in each locule, ovate to oblate somewhat bilobed fruits with the seed-bearing portion generally narrower than the wings, entire leaflets (except in S. giraldiana (Parra-Os.) Appelhans \& Kessler,
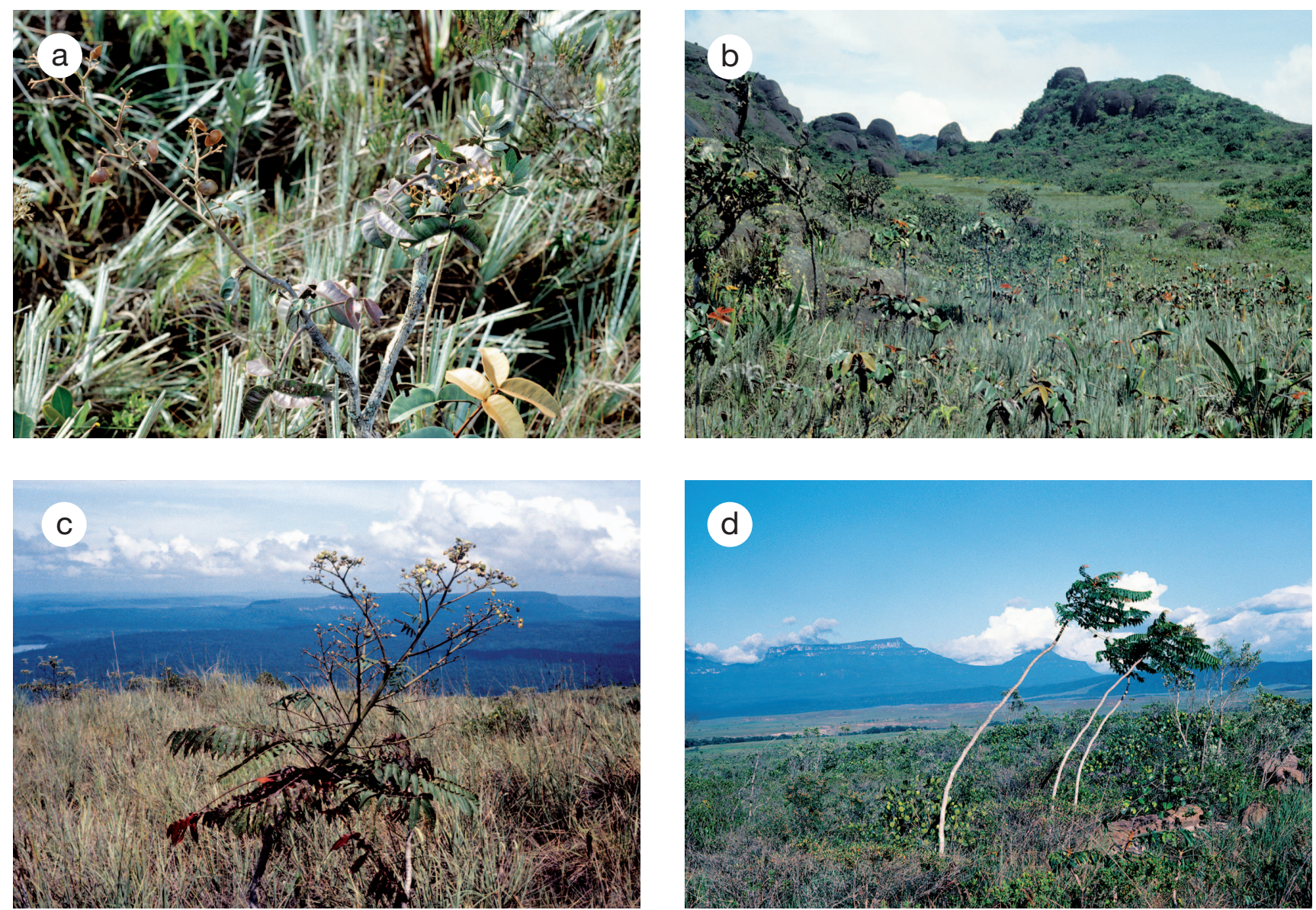

Fig. 4. Venezuelan Guayana species of the genus Sohnreyia (Rutaceae): a, b, S. maigualidensis, Sierra de Maigualida, ca. 2000 m; a, habit; b, habitat; c, d, S. ulei, Gran Sabana, ca. 1000 m; c, habit; d, habitat. (Photos O. Huber). 
which are serrate), seeds without endosperm and rounded embryos are included in Sobnreyia (formerly included in Spathelia subgen. Sohnreyia (K. Krause) Cowan \& Brizicky and Spathelia subgen. Diomma (Engler ex Harms) Cowan \& Brizicky; Cowan \& Brizicky, 1960; Parra-Osorio, 2005; Appelhans \& al., 2011).

The genus Sohnreyia comprises, besides S. maigualidensis (here described), S. ulei, an endemic of the Guayana Highlands in the Roraima Sandstone Formation, S. giraldiana, from a granitic outcrop in Departamento de Vichada, Colombia, S. excelsa K. Krause, from Central Amazonia, and S. terminalioides (A.H. Gentry) Appelhans \& Kessler, from an ecologically similar but geographically distant area of in Western Amazonia (white sand woodlands on the Río Nanay near Iquitos, departamento de Loreto, Perú; Cowan \& Brizicky, 1960; Kallunki, 2005; ParraOsorio, 2005). Sohnreyia ulei and S. giraldiana belong to Spathelia subgen. Diomma as defined by Cowan \& Brizicky (1960) whereas S. excelsa constitutes the monotypic Spathelia subgen. Sohnreyia (Cowan \& Brizicky, 1960; Parra-Osorio, 2005); S. terminalioides has not yet received subgeneric assignation.

The new species can be easily differentiated from all previously described taxa within Spathelia and Sobnreyia by its paucifoliolate leaves (only 2-5 pairs of leaflets vs. 7-24 pairs in the rest of the species), densely covered by a ferrugineous indumentum of mixed stellate and simple hairs and by its small inflorescences, both terminal and axillary (vs. exclusively terminal).

\section{Distribution, habitat, and phenology}

The new species seems to be restricted to small, open areas scattered in the highlands (1800-2200 m) of Sierra de Maigualida, located in the north-central part of the Guayana phytogeographic region and the Pantepui Province (Huber \& al., 1997). It is a mostly monopodial or rarely ramified shrub, with a very sparse crown, which grows in large colonies of numerous individuals that are usually separated several meters from each other. The average height is between 1-3 m, but shorter (juvenile) and taller individuals (up to $7 \mathrm{~m}$ ) have also been observed, the latter especially on rocky substrates and in the ecotone zone with the low elfin forest.

Sohnreyia maigualidensis communities appear to prefer deep, water-saturated peat soils of valley plains (see Huber \& García, 2011), which are covered by a dense, unique tepui grassland dominated by Axonopus villosus Swallen (Poaceae), Kunhardtia rbodantha Maguire (Rapateaceae), and Orectanthe sceptrum (Oliv.) Maguire (Xyridaceae), together with numerous herbs of Eriocaulaceae, Xyridaceae, Cyperaceae, Liliaceae, and terrestrial Bromeliaceae. Among the common shrub species are Clusia sp. (Clusiaceae), Phyllanthus obfalcatus and P. buberi (Euphorbiaceae), and Marcetia taxifolia (A. St.-Hil.) DC. (Melastomataceae). Similar to Sohnreyia ulei, widespread in the Guayana uplands and highlands, this new species also seems to show massive synchronous flowering cycles as seen from fruiting specimens; so far, however, only a few, occasional, flowering individuals have been observed during the eight expeditions made in March, May, November, and December, which correspond to the beginning (Nov/Dec) and the end (March/May) of the dry season, respectively.

\section{Paratypi}

VENEZUELA. Amazonas: Depto. Atures, Sierra de Maigualida, sector nor-oriental, altiplanicie disectada de granito en las cabeceras nor-orientales del Río Iguana, afluente del Río Ventuari, $05^{\circ} 40^{\prime} \mathrm{N}, 65^{\circ} 08^{\prime} \mathrm{W}$, \pm 2100 m, 4-V-1990, (fl), O. Huber 13097 (unicata, VEN-377774); sector centro-norte, herbazales arbustivos sobre vertiente inclinada hacia el SE, en las cabeceras del Río Asita, 05³2’ N, 65¹0’ W, \pm 1700 m, 5-XII-1992, (fr), O. Huber \& J. Rosales 13420 (MYF, VEN); Depto. Atures, Sierra Maigualida, NW sector, small valley along an upper tributary of Caño

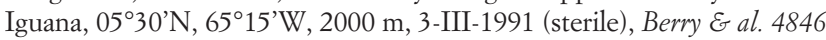
(NY, MO, n.v.); Mun. Atures, Sierra Uasadi, sector nor-oriental, cabeceras nor-orientales del Río Asita, pequeña planicie sobre granito con

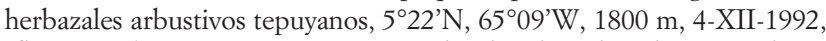
(fl), O. Huber 13415 (MYF, VEN, to be distributed, 5 sheets). Bolívar: Distrito Cedeño, Sierra de Maigualida, sector nor-oriental, altiplanicie tepuyana ubicada en las cabeceras del Río Yudi ["Río Chajura" in the label], afluente occidental del Río Erebato, aprox. $100 \mathrm{~km}$ (en línea recta) al SW del Campamento EntreRíos, 05 33’ N, 65 13' W, \pm 2100 m, 28 Mar 1988 (sterile), O. Huber 12719 (VEN-377775, NY).

\section{Turneraceae}

Although Turneraceae could be circumscribed within Passifloraceae as subfamily Turneroideae on the basis of molecular phylogenetic evidence (APG III, 2009; Stevens, 2011), in this contribution it is retained as a distinct family.

\section{Turnera maigualidensis J.R. Grande \& Arbo, sp. nov.}

Typus: Venezuela. Amazonas: Cabeceras nororientales del Río Asita en el sector nororiental de la Sierra de Maigualida, extensos herbazales sobre glacis poco inclinado hacia el W, 531'50”'N, 6509'14’'W, \pm 1700 m, 9-III-1996 (fl), O. Huber E R. Riina 13654 (holotypus, VEN; isotypus, CTES).

A reliquis Turnerae speciebus hactenus descriptis differt: foliis imbricatis solum in apice ramorum praesentibus, margine revolutis, singulo pari glandularum cupuliformium ad unionem laminae cum petiolo, petalisque apice apiculatis necnon pilosis.

Fruticulus pauce ramosus, usque $1.5 \mathrm{~m}$ altus, ramis 2-3(6)furcatis, indumento strigoso e pilis simplicibus $0.3-0.4 \mathrm{~mm}$ longis, ochraceo-auratis in junioribus caulibus, foliis calyceque praesentibus. Caulis conspicue cicatricosus, stipulis persistentibus paucis centimetris sub loco abscissionis foliorum locatis. Cortex fusco-griseus, fissuris transversalibus praeditus. Folia imbricata, in apice ramorum; stipulis 1.1-1.8 mm longis, subulatis, dense pilosis, patentibus; petiolis dense strigosis, 2-3.5 $\mathrm{mm}$ longis; laminis 1.5-2.6 cm longis, 2-7 mm latis, ex elliptico paulo obovatis, basi cuneatis, per petiolum breviter decurrentibus, margine revolutis, denticulatis, duobus denticulis basalibus nectariis cupuliformibus e rotundato oblongis, 0.2$0.3 \mathrm{~mm}$ diametro, in foliis maturis difficulter observatis, caeteris denticulis coleteribus donatis. Inflorescentiae simplices, apicem versus congestae; pedunculo florali libero $2.7-4 \mathrm{~mm}$ longo, prophyllis ovato-ellipticis, laxe strigosis, margine paulo 


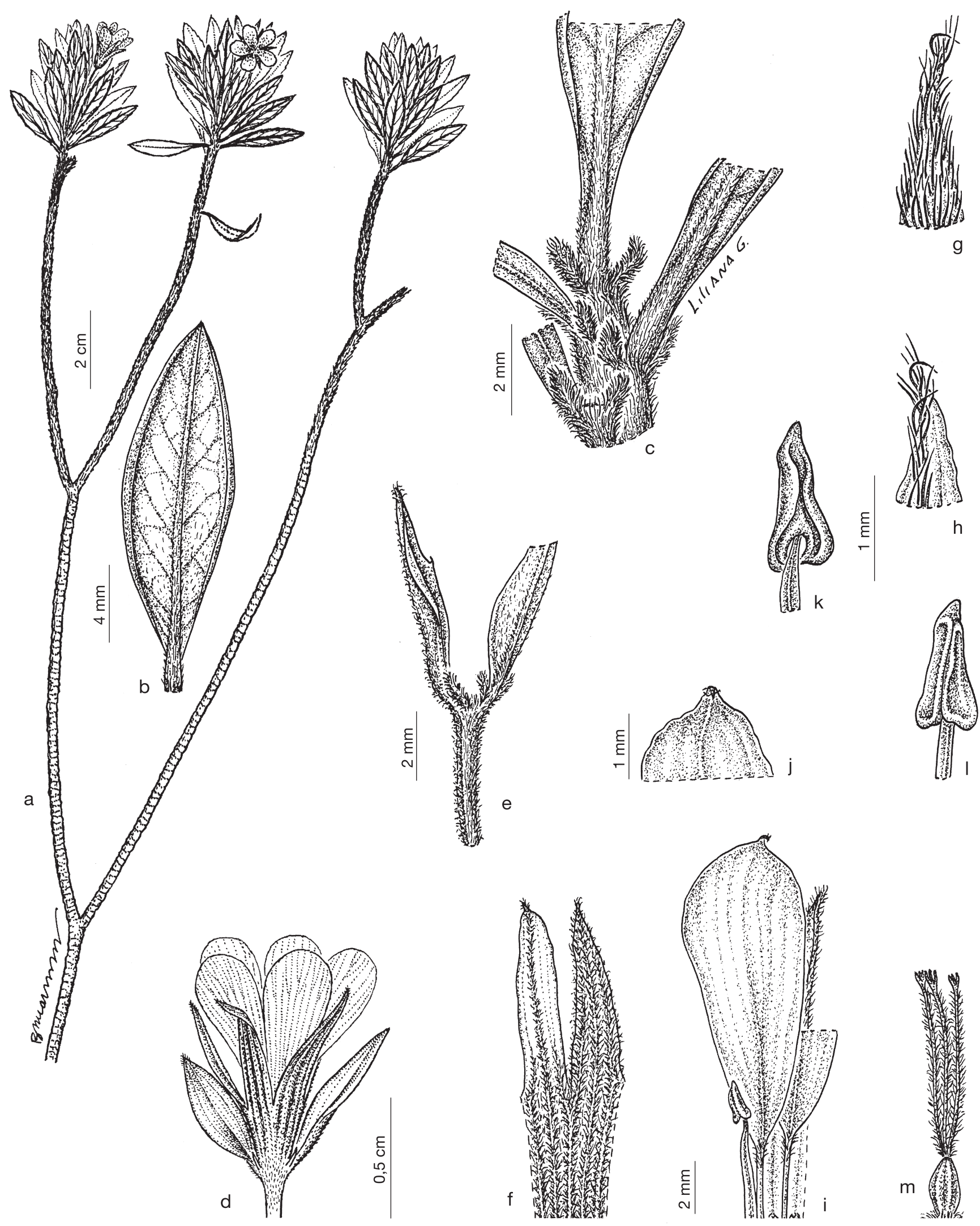

Fig. 5. Turnera maigualidensis: a, flowering branch; $\mathbf{b}$, leaf, abaxial side; $\mathbf{c}$, portion of branch, showing the insertion of the leaves with pilose stipules, persistent after leaf abscission; $\mathbf{d}$, flower with prophylls; e, floral pedicel and prophylls with stipules; f, outer portion of the calyx, showing indumentum of inner and outer lobe; $\mathbf{g}$, apex of an outer lobe; $\mathbf{h}$, apex of an inner lobe; $\mathbf{i}$, calyx tube portion, inside, with two petals and one stamen adnate, the scars of two stamens have been squared; j, apical portion of a petal; $\mathbf{k}$, anther, dorsal view; l, anther, ventral view; $\mathbf{m}$, longistylous gynoecium. (Figs. a, d, Bruno Manara; figs. b, e-m, Liliana Gómez; all figures from the type specimen). 
revolutis et denticulatis, 5-7 $\mathrm{mm}$ longis, 1-2 $\mathrm{mm}$ latis, in receptaculo insertis. Calyx 7-12.5 mm longus, sepalis a basi ad 2.8-3.5 mm conniventibus. Tubus calycinus extus dense strigosus, intus glaber, lobulis anguste triangularibus, 5-9 mm longis, 1.6-1.7 mm latis, venis tribus (3) prominentibus, carinantibus. Petala $10 \mathrm{~mm}$ longa, 3-3.5 $\mathrm{mm}$ lata, dilute lutea, glabra, excepto ungue in insertione cum lamina adaxialiter, et apice apiculata, ubi villosa. Fructus seminaque incognita.

Shrubs to $1.5 \mathrm{~m}$, sparsely ramified, branches 2-3(6)forked, indument strigose, composed of 0.3-0.4 mm long golden-ochraceus short simple hairs, over leaves and calyces, as well as in young stems. Stems 2.7-3.9 mm in diameter below terminal ramifications, conspicuously cicatricose, stipules persistent several centimeters below the level of abscission of the foliage; bark grayish brown, with transverse cracks; young stems strigose, turning glabrous with age. Foliage imbricate, disposed toward the apex of branches. Leaves coriaceous, petiolate; stipules1.1-1.8 mm long, subulate, densely pilose, patent; petioles linear to obcuneate, densely strigose, $2-3.5 \mathrm{~mm}$ long; leaf blades green, slightly discolorous in dried material, $15-26 \times 2-7 \mathrm{~mm}$, elliptic to slightly obovate, base cuneate, shortly decurrent on the petiole, margin revolute, denticulate, the basal pair of denticles with cupulliform nectaries rounded to oblong 0.2 $0.3 \mathrm{~mm}$ in diameter, hardly distinguishable in mature leaves, remaining denticles with colleters; apex acute to slightly acuminate; upper leaf surface glabrous, except the midvein slightly sunken, with dense appressed hairs to the base and scattered hairs to the apex, secondary veins slightly prominent when dry; underside glabrous except the midrib and prominent lateral veins, with scattered appressed hairs, sometimes third-order veins also slightly prominent. Inflorescences simple, flowers axillary, possibly heterostylous (only longistylous flowers seen) towards the apex of the foliated portions of the branchlets, floral peduncle free 2.7-4 mm long, prophylls ovate-elliptic, loosely strigose, margin slightly revolute and denticulate (2.1-3)5-7 $\times(0.15-0.2) 1-2 \mathrm{~mm}$, with linear-laciniate stipules, strigose, of 0.7 to $1.2 \mathrm{~mm}$ long, inserted at the calyx base. Calyx 7 $12.5 \mathrm{~mm}$ long, light brown, sepals connate from the base to 2.8-3.5 mm high, the resulting tube densely strigose abaxially, glabrous adaxially; lobes narrowly triangular, 5-9 × 1.6$1.7 \mathrm{~mm}$, with 3 prominent veins, forming carinae, loosely strigose abaxially, glabrous adaxially. Petals $10 \times 3-3.5 \mathrm{~mm}$, spatulate, apiculate, pale yellow, glabrous except at the junction of the claw with the blade, which is villous on adaxial side, and at the apex. Stamens with complanate-subulate filaments in dry material, $3 \mathrm{~mm}$ long, with the lower 0.5-0.7 $\mathrm{mm}$ adnate to the calyx, anthers sagittate $1 \times 0.6 \mathrm{~mm}$, with introrse longitudinal dehiscence, base emarginate, apex apiculate, filament inserted dorsally to $0.25 \mathrm{~mm}$ from the base, abundant pollen, with grains ellipsoid, amber-hyaline. Gynoecium 2-4 mm longer than the stamens; ovary ovoid, glabrous, 1.2-1.5 mm long., 3 styles 4.8-6 mm long, with simple hairs more or less appressed; stigmas pennicillate, 0.5 $0.6 \mathrm{~mm}$ long., with 4-6 branches. Fruits and seeds unknown. (Fig. 5).

\section{Etymology}

The specific epithet refers to the type locality.

\section{Diagnostic characters}

The new species differs from other described species of Turnera L. by the overlapping leaves, congested towards the apex, with revolute margins, a sole pair of cupuliform nectaries at the junction of the petiole, and petals with the apex apiculate and villose. Turnera maigualidensis belongs to series Salicifoliae Urb., which includes species having stipules small or rudimentary, upper leaf surface glabrous or subglabrous, solitary flowers, free flower pedicel, narrow prophylls, ovary glabrous and styles pilose. Upright long branches foliated only towards the apex, are present like in many specimens of T. glaziovii Urb. and T. rupestris, and in T. arcuata Urb. (series Turnera). Leaf base is somewhat prominent and stipules are persistent after leaf abscission as in T. cicatricosa Arbo, the pedicel is not developed, as in $T$. venosa Urb. The new species differs from all species in the series by presenting small imbricate leaves with revolute margins. The latter is a rare character in the genus, present in a few species of series Leiocarpae Urb. and series Sessilifoliae Arbo.

\section{Distribution and habitat}

According to the information from collection labels, this new species is a low shrub, fairly scarce in its natural habitat. It is only known from the type collection.

\section{ACKNOWLEDGEMENTS}

J.R. Pirani (SPF) made useful comments on the circumscription of the genus Sobnreyia K. Krause (Rutaceae). B.K. Holst (SEL) provided information on endemism and geographical distribution of the Araliaceae, Bromeliaceae and Myrtaceae, while S. Nozawa (VEN) provided it on the Asteraceae. B. Manara (VEN) translated into Latin the descriptions of the new species and drew Figs. 1-3 and 5a,d, L. Gómez (CTES) drew Figs. 5b,e-m, G. Pieszko (CTES) diagrammed Fig. 6, and P. Estrada scanned the photographic material (Figs. 4a-d). The staff of the herbaria CTES, DAV, M, MA, MYF, NY, and VEN made available their collections for study.

\section{REFERENCES}

Anderson, W.R. 1995. Notes on neotropical Malpighiaceae-V. Contributions from the University of Michigan Herbarium 20: 15-36.

APG III. 2009. An update of the Angiosperm Phylogeny Group classification for the orders and families of flowering plants: APG III. Botanical Journal of Linnean Society 161: 1-5-121.

Appelhans, M.S., Smets, E., Razafimandimbison, S.G., Haevermans, T., van Merle, E.J., Couloux, A., Rabarison, H., Randrianarivelojosia M. \& Keßler, P.J.A. 2011. Phylogeny, evolutionary trends and classification of the Spathelia-Ptaeroxylon clade: morphological and nomenclatural insights. Annals of Botany 107: 1259-1277.

Austin, D.F. 1973. The American Erycibeae (Convolvulaceae): Maripa, Dicranostyles, and Lysiostyles-I. Systematics. Annals of the Missouri Botanical Garden 60(2): 306-412.

Bell, G. 1980. The costs of reproduction and their consequences. The American Naturalist 116(1): 45-76.

Berry, P.E., Huber, O. \& Holst, B.K. 1995. Floristic Analysis and Phytogeography. In: Berry, P.E. \& al. (eds.), Flora of the Venezuelan Guayana, Vol. 1: 161-191. Timber Press, Portland. 
Beurton, C. 2008. Rutaceae. In: Greuter, W. \& Rankin Rodríguez, R. (eds.), Flora de La República de Cuba 14: 1-134. Gantner Verlag, Ruggel, Liechtenstein.

Borhidi, A.L. \& Muñiz, O. 1971. Combinationes novae Florae Cubanae I. Botanikai Közlemenyek 58(3): 175-177.

Chase, M.W., Morton, C.M. \& Kallunki, J.A. 1999. Phylogenetic relationships of Rutaceae: a cladistic analysis of the subfamilies using evidence from $\mathrm{rbcL}$ and atpB sequence variation. American Journal of Botany 86(8): 1191-1199.

Cowan, R.S. \& Brizicky, G.K. 1960. Taxonomic relationships of Diomma Engler ex Harms. Memoirs of the New York Botanical Garden 10(2): 58-64.

Croat, T.B., Outman, R. \& Kostelac, C.V. 2010. New species of Araceae from Venezuela and the Guianas. Willdenowia 40(1): 137-146.

Frodin, D.G. 1993. Studies in Schefflera (Araliaceae), VI. New species and subordinate taxa in the Venezuelan Guayana and inmediately adjacent. Novon 3(4): 367-403.

Groppo, Jr., M., Pirani, J.R., Salatino, M.L., Blanco, S. \& Kallunki, J.A. 2008. Phylogeny of Rutaceae based on two non-coding regions from cpDNA. American Journal of Botany 95: 985-1005.

Hoffmann, P., Kathriarachchi, H., Wurdack, K. 2006. A phylogenetic classification of Phyllanthaceae (Malpighiales; Euphorbiaceae s.1.). Kew Bulletin 61(1): 37-52.

Holst, B.K. 1993. New species and a new combination in the subfamily Pitcairnioideae (Bromeliaceae) from the Guayana Shield. Journal of the Bromeliad Society 43(6): 248-256.

Holst, B.K. 2002. New species and notes on Myrtaceae from northern South America. Selbyana 23(2): 137-180.

Holst, B.K. 2003. Marlierea (Myrtaceae). In: Berry, P.E \& al. (eds.), Flora of the Venezuelan Guayana 7: 40-53. Missouri Botanical Garden Press, St. Louis.

Huber, O. 1995. Geographical and physical features. In: Berry, P.E. \& al. (eds.), Flora of the Venezuelan Guayana 1: 1-61. Missouri Botanical Garden Press, St. Louis.

Huber, O., Rosales, J. \& Berry, P.E. 1997. Estudios botánicos en las montañas altas de la cuenca del Río Caura (Estado Bolívar, Venezuela). In: Huber, O. \& Rosales, J. (eds.), Ecología de la Cuenca del Río Caura, Venezuela. II. Estudios especiales. Scientia Guaianæ 7: 441-468. Caracas.

Huber, O. \& García, P. 2011. The Venezuelan Guayana Region and the study areas: Geo-ecological characteristics. In: Zinck, A. \& Huber, O. (eds.), Peatlands of the Western Guayana Highlands, Venezuela: properties and paleogeographic significance of peats. Ecological Studies 217: 29-89. Springer-Verlag, Berlin, Heidelberg, New York.

Janzen, D.H. 1976. Why Bamboos wait so long to flower. Annual Review of Ecology and Systematics 7: 347-391.

Kallunki, J. 2005. Rutaceae. In: Berry \& al. (eds.), Flora of the Venezuelan Guayana 9: 1-39. Missouri Botanical Garden Press, St. Louis.

Kirkbride, J.H., jr. 1997. Manipulus rubiacearum-VII. BioLlania (Edición especial) 6:393-406.

Knox, E.B., Muasya, A.M. \& Muchhala, N. 2008. The predominantly South American clade of Lobeliaceae. Systematic Botany 33(2):462468.

Lammers, T.G. 1998. Review of the neotropical endemics Burmeistera, Centropogon, and Siphocampylus (Campanulaceae: Lobelioideae), with descripction of 18 new species and a new section. Brittonia 50: 233-262.

León, Hermano (Sauget, J.S.) \& Alaín, Hermano (Liogier, E.E.). 1951. Rutaceae. In: Flora de Cuba 2: 389-392.
Linné, C. 1760. Amoenitates academicae; seu dissertationes variae physicae, medicae, botanicae, antehac seorsim editae, nunc collectae et auctae, cum tabulis aenaeis $5: 377$. Holmiae, sumtu \& literis direct. Laurentii Salvii. [http://www.botanicus.org/item/31753000806411].

Madriz, R. 2008. Campanulaceae. In: Hokche, O. \& al. (eds.), Nuevo Catálogo de la Flora Vascular de Venezuela. Fundación Instituto Botánico de Venezuela "Dr. Tobías Lasser", Caracas.

McNeill, J., F.R. Barrie, H.M. Burdet, V. Demoulin, D.L. Prado, P.C. Silva, J.E. Skog, J.H. Wiersema. 2006. International Code of Botanical Nomenclature (Vienna Code). Adopted by the Seventeenth International Botanical Congress. Vienna, Austria, July 2005. [http://ibot.sav.sk/ $\mathrm{icbn} / \mathrm{main} . \mathrm{htm}]$.

Morillo, G. 1993. Asclepiadaceae nuevas o interesantes de Venezuela y Guyana. Ernstia 3(2): 61-70.

Nozawa, S., Grande, J.R. \& Huber, O. 2010. Botanical Novelties from Sierra de Maigualida, southern Venezuela. I. Anales del Jardín Botánico de Madrid 67(2): 195-202.

Parra-Osorio, C. 2005. Primer registro de Spathelia L. (Rutaceae) y una nueva especie del género para Colombia. Caldasia 27(1): 17-23.

Proctor, G.R. 1982. More additions to the flora of Jamaica. Journal of the Arnold Arboretum 63(3): 199-315.

Pruski, J.F. 1992. Compositae of the Guayana Highland-VII. Noteworthy species of Chromolaena and Mikania (Eupatorieae) from Venezuela. Brittonia 44(2): 213-219.

Pruski, J.F. 2011. Compositae of the Guayana Highland-XIV. Four new species of Calea (Neurolaeneae) from tepui summits in Venezuela. Phytoneuron 2011-52: 1-9.

Rodríguez, L., M. Carlsen, M. Bevilacqua \& M. García. 2008. Colección de plantas vasculares de la cuenca del Río Caura (estado Bolívar) depositada en el Herbario Nacional de Venezuela. Acta Botanica Venezuelica 31(1): 107-250.

Sastre, C. 2001. New Ouratea species (Ochnaceae) from Venezuela and adjacent countries. Novon 11: 105-118.

Stein, B.A. 1998. Campanulaceae. In: Berry, P.E. \& al. (eds.), Flora of the Venezuelan Guayana 4: 122-129. Missouri Botanical Garden Press, St. Louis, Missouri.

Stern, W.L. \& Brizicky, G.K. 1960. The morphology and relationships of Diomma, gen. inc. sed. Memoirs of the New York Botanical Garden 10(2):38-57.

Stevens, P.F. 2011. Angiosperm Phylogeny Website. Version 9, June 2008 [and more or less continuously updated since]. [http://www.mobot.org/ MOBOT/research/APweb/]

Steyermark, J.A. 1978. New taxa from Cerro Marahuaca. Brittonia 30: 50-53.

Steyermark, J. A. 1988. Flora of the Venezuela Guayana VI. Aquifoliaceae. Annals of the Missouri Botanical Garden 75: 320-333.

Webster, G.L. 1999. Phyllanthus (Euphorbiaceae). In: Berry, P.E. \& al. (eds), Flora of the Venezuelan Guayana 5: 191-205. Missouri Botanical Garden Press, St. Louis.

Wimmer, F.E. 1953. Campanulaceae-Lobelioideae, Teil II. In: Mansfield, R. (ed.), Das Pflanzenreich, IV, 276b (107 Heft). Akademie Verlag, Berlin.

Wurdack, J.J. 1990. Certamen Melastomataceae XXXIX. Phytologia 69(5): 316-327.

Associate Editor: J. Fuertes Aguilar Received: 4-XI-2011 Accepted: $12-\mathrm{V}-2012$ 
